\title{
Evaluasi Kebijakan Pemerintah Dalam Penyelenggaraan Pendidikan Agama Islam
}

\author{
Muhammad Idrus ${ }^{1}$
}

\begin{abstract}
The current paper critisizes government's policy on Islamic religion education implementation, in term of the organizer/ administrator and subject matters. Government Regulation (Peraturan Pemerintah) No 55/ 2007 explicitly explained about how Islamic religion education and other religions education organized and administered. This paper found that the regulation has several critical points on its implementation, organization, and administration. Therefore, it is urgent for Ministry of Religious Affair and Ministry of Education to make synergic cooperation on implementing Islamic religion education development, whether on its education system, infrastructures, subject materials, and human resource development. If this cooperation appears to be hard to implement, Ministry of Religious Affair better to return its role in managing Islamic education to Ministry of Education. Means, this paper recommends the government to revise the regulation on religions education system.
\end{abstract}

Keywords: Islamic religion education, government regulation on religions education.

\footnotetext{
${ }^{1}$ Penulis adalah dosen tetap Program Studi Pendidikan Agama Islam Fakultas Ilmu Agama Islam UII
}

\section{A. Pendahuluan}

Lazimnya, segala pembaharuan dalam bidang pendidikan harus dipahami sebagai upaya manusia untuk membebaskan dirinya dari segala keterbelakangan (backwardness) dan ketidak-tahuan yang dimilikinya. Selain itu, secara lebih normatif, pendidikan merupakan cara manusia untuk mengenal dirinya dalam konteks kemanusiannya, serta sebagai upaya mendekatkan dirinya kepada penciptanya (Allah I) melalui perspektif kemanusiaan yang dimilikinya.

Bagi kebanyakan negara yang sedang berkembang - bahkan negara maju sekalipun pendidikan berfungsi uintuk menyiapkan sumber daya manusia (SDM). Secara normatif pendidikan diharapkan dapat memberi petunjuk bagi keberlangsungan kehidupan sesuai dengan tata nilai ideologis dan kultural bangsa, sehingga proses yang berlangsung dalam dunia pendidikan harus dapat memberi kesadaran kepada manusia akan potensi "kemanusiaan" yang dimilikinya

Lebih dari itu pendidikan harus mampu merangsang manusia untuk mempergunakan potensi tersebut sesuai dengan tata nilai kemanusiaan. Selain itu, secara material pendidikan harusnya dapat memberikan pengetahuan yang memajukan dan mempertinggi kualitas hidup, baik dalam skala kehidupan pribadi, bermasyarakat maupun bernegara. Bagi masyarakat bangsa Indonesia, masalah pendidikan dengan sendirinya menjadi salah satu agenda yang menduduki posisi penting. Kesadaran akan hal inilah yang menjadikan pemerintah (negara) memiliki kewajiban untuk menyelenggarakan porses pendidikan bagi warga negaranya. 
Hanya saja jika dicermati, tampak kesenjangan antara tingginya animo masyarakat untuk mendapatkan pendidikan sebanyakbanyaknya dengan kemampuan pemerintah dalam menyelenggarakan pendidikan. Menyadari keterbatasan yang dimiliki, negara membuka peluang kepada setiap individu warga negara, kelompok masyarakat dan lembaga yang ada di masyarakat lainnya untuk ikut berpartisipasi memecahkannya.

Pada sisi inilah banyak lembaga-lembaga Islam yang turut mengambil peluang untuk ikut berkompetisi menyelenggarakan lembaga pendidikan, tentunya dengan tujuan selain sebagai wujud partisipasi aktif, juga adanya keharusan untuk melindungi umat dengan cara menyelenggarakan pendidikan yang sesuai dengan agama yang dianutnya.

\section{B. Pembahasan}

\section{Kebijakan Tentang Penyelenggaraan Pendidikan Islam}

Terminologi pendidikan Islam bagi penulis merujuk pada konteks makna institusi, proses dan kurikulum (Idrus, 1997). Institusi akan merujuk pada lembaga-lembaga pendidikan Islam formal (mulai dari MI, M.Ts., MA PT Islam) maupun non-formal (pondok pesantren, sekolah diniyah, TPA). Untuk pendidikan berbentuk perguruan tinggi Islam, meski untuk pendidikan tinggi, Zamroni (1995) pernah mengajukan sinyalemen bahwa model pendidikan tinggi Islam pada dasarnya merupakan implementasi dari sistem pendidikan tinggi sekuler barat yang ditambah dengan mata kuliah agama Islam.

Sementara itu, proses merujuk pada situasi interaktif antara pendidik dengan peserta didik beserta lingkungan pendidikan yang menyertainya. Dengan begitu, proses yang berlangsung di dalamnya seharusnya diarahkan untuk menumbuhkan kepribadian manusia yang seimbang dalam pelbagai aspek, dan mampu mengantarkan manusia untuk menyerahkan diri kepada Allah 젰 baik secara individual ataupun kolektif. Adapun kurikulum (subject matter) dapat dipahami sebagai kurikulum atau dalam makna yang lebih sempit adalah mata pelajaran/mata kuliah yang diberikan kepada peserta didik.

Di lihat dari sisi manapun, pendidikan Islam memiliki peran dalam konteks pendidikan nasional. Hanya saja harus pula dimaklumi dan dipahami jika hingga hari ini secara kelembagaan pendidikan Islam kerap menempati posisi kedua dalam banyak situasi. Sebagai misal, jurusan yang menawarkan pendidikan Islam kurang banyak peminatnya jika dibandingkan dengan jurusan lain yang dianggap memiliki orientasi masa depan yang lebih baik. Dalam hal pengembangan kelembagaan akan pula terlihat betapa program studi/ sekolah yang berada di bawah pengelolaan dan pengawasan Kementerian Agama tidak selalu yang terjadi di bawah pembinaan Kementerian Pendidikan Nasional, bahkan harus dengan tertatih untuk menyesuaikan dengan yang terjadi di sekolah-sekolah umum tersebut.

Meski disadari betapa pentingnya posisi pendidikan Islam dalam konteks pendidikan nasional, namun, harus pula diakui hingga saat ini posisi pendidikan Islam belum beranjak dari sekadar sebuah subsistem dari sistem besar pendidikan nasional.

\section{Evaluasi Kebijakan Pemerintah Dalam Penyelenggaraan PAI}

Keluarnya Peraturan Pemerintah (PP) Nomor 55 tahun 2007 tentang pendidikan agama dan pendidikan keagamaan, diharapkan dapat membawa perubahan pada sisi 
menajerial dan proses pendidikan Islam. PP tersebut secara eksplisit mengatur bagaimana seharusnya pendidikan keagamaan Islam (bahasa yang digunakan PP untuk menyebut pendidikan Islam), dan keagamaan lainnya diselenggarakan.

Dalam pasal 9 ayat (1) disebutkan, "Pendidikan keagamaan meliputi pendidikan keagamaan Islam, Kristen, Katolik, Hindu, Buddha, dan Khonghucu." Pasal ini merupakan pasal umum untuk menjelaskan ruang lingkup pendidikan keagamaan. Selanjutnya pada ayat (2) pasal yang sama disebutkan tentang siapa yang menjadi pengelola pendidikan keagamaan baik yang formal, non-formal dan informal tersebut, yaitu Menteri Agama.

Dari sini jelas bahwa tanggungjawab dalam proses pembinaan dan pengembangan pendidikan Islam/dan atau keagamaan Islam menjadi tanggungjawab menteri agama. Tentunya mengingat posisi menteri agama bukan hanya untuk kalangan Islam saja, maka beban menteri agama juga melebar pada penyelenggaraan pendidikan agama lain non Islam, di samping beban administratif lain terkait dengan ruang lingkup penyelenggaraan agama dan prosesi keagamaan untuk seluruh agama-agama yang diakui di Indonesia.

Mencermati betapa beratnya beban yang diemban oleh menteri agama, tampaknya memang perlu dipikir ulang untuk kembali mengajukan ide penyelenggaraan pendidikan dalam satu atap di bawah departemen pendidikan saja, dan tidak terpecah sebagaimana sekarang ini.

Salah satu alasan terkuat mengapa perlu penyatuan pendidikan di bawah satu atap adalah, dalam menentukan kebijakan pengelolaan pendidikan, terutama yang berkaitan dengan masalah akademis selama ini Kemenag selalu mengikuti kebijakan yang dibuat oleh
Kementerian Pendidikan Nasional. Inovasiinovasi pembelajaran lebih banyak muncul kali pertama dari Kementerian Pendidikan Nasional bukan dari Kemenag. Dengan sendirinya, Kemenag selalu menunggu adanya inovasi ataupun kebijakan pengelolaan yang akan dikeluarkan oleh Kementerian Pendidikan Nasional. Dalam catatan sejarah pendidikan nasional, hampir tidak banyak inovasi yang dilakukan Kemenag yang benar-benar berbeda dengan yang dikembangkan oleh Kementerian Pendidikan Nasional.

Kenyataan ini jelas tidak dapat dipungkiri, cermati saja bagaimana kebijakan tentang Kurikulum Berbasis Kompetensi (KBK) dan Kurikulum Tingkat Satuan Pendidikan (KTSP) terasa betapa dominasi Kementerian Pendidik an Nasional dalam pengembangan dan penerapannya begitu kentara. Sementara itu, Kemenag tetap setia mengikutinya. Untuk kasus yang lebih baru, Kemenag juga tidak memiliki kekuasaan untuk menentukan mata uji apa saja yang harus ditempuh oleh peserta didik yang mengikuti pendidikan di MTs dan MA saat penentuan kelulusan.

Selain itu dari sisi manajerial madrasah dikelola Kementerian Agama yang tidak memiliki dana yang cukup untuk membiaya madrasah yang jumlahnya sangat banyak, di samping Kemenag tidak memiliki sumber tenaga kependidikan yang memadai untuk mengelola madrasah, jika dibandingkan dengan Kemendiknas.

Sebagai misal anggaran Dirjen Pendidikan Islam tahun 2007 adalah senilai Rp 7 triliun. Angka sebesar itu diperuntukkan bagi banyak komponen pendidikan seperti gaji guru dan tenaga kependidikan $(57,1 \%)$, dana BOS BKM, BOS buku $(25,7 \%)$, sisanya sebagai anggaran tupoksi 4 direktorat Kemenag pusat dan bidang Mapenda serta Pontren di 32 Kanwil Kemenag 
Provinsi (17,1\%) atau sekitar Rp 1,2 triliun. Saat ini anggaran pendidikan Islam di Kemenag diprediksi 20\% dari anggaran pendidikan di Depdiknas (bukan dari APBN) (Mulyana. 2008).

Untuk tingkat pendidikan tinggi, ketergantungan Kemenag terhadap Kementerian Pendidikan Nasional juga terasa. Sebut saja permasalahan tentang pengakuan kepangkatan (jabatan akademik) dosen perguruan tinggi Islam yang masih tetap harus sepengtahuan dari Kementerian Pendidikan Nasional. Bahkan Kementerian Pendidikan Nasional-lah yang menentukan kepangkatan dosen PT Islam untuk jabatan Lektor Kepala dan Guru Besar.

Jalur yang harus ditempuh seorang dosen PT Islam untuk mendapatkan jabatan guru besar pertama yang bersangkutan harus mengajukan pada institusinya, kemudian mengajukan ke Kemenag di Jakarta, setelah ke Kementerian Pendidikan Nasional. Surat Keputusan pengangkatan guru besarpun ditandatangani oleh Mendiknas, bukan oleh Menag. Jalur ini akan semakin panjang jika dosen tersebut adalah dosen PT Islam Swasta, yang harus pula melewati Kopertais dan Kopertis. Hal ini jelas suatu ironi, betapa penyelenggara pendidikan tidak dapat berbuat banyak untuk menentukan langkah-langkah inovasi yang dibutuhkan dalam proses penyelengaraan institusi pendidikan.

Selain itu seandainya terjadi penyimpangan dalam penyelenggaraan pendidikan keaagamaan, maka jika untuk pendidikan tinggi maka posisi menteri agama sebagaimana pasal 7 ayat (1) hanya sebagai pemberi pertimbangan dan bukan pengambil keputusan. Adapun pengambil keputusan untuk jenjang pendidikan dasar dan menengah dilakukan oleh bupati/ walikota, dan masukan pertimbangan diberikan oleh Kepala Kantor Kementerian Agama Kabupaten/Kota. Sekali lagi hal ini menunjuk- kan betapa Kemenag beserta jajarannya hingga yang paling bawah, tidak memiliki kekuasaan dalam proses penyelenggaraan pendidikan keagamaan sekalipun.

Untuk jenjang pendidikan dasar dan menengah, lembaga penyelenggara pendidikan keagamaan Islam adalah MI, MTs dan MA. Meski sebenarnya penyebutan lembagalembaga tersebut tidak secara eksplisit, namun sebagai penjelasan tentang kemungkinan perpindahan peserta didik dalam jenjang pendidikan yang setara (Pasal 11). Dalam UU Sisdiknas Nomor 20 tahun 2003 Pasal 17 ayat (2) juga memang disebutkan untuk jenjang pendidikan dasar, yaitu MI, MTs, dan Pasal 18 ayat (3) jenjang pendidikan menengah bagi pendidikan Islam adalah MA dan MAK. Hanya saja khusus untuk pendidikan keagamaan, baik dalam UU Sisdiknas Pasal 30 ayat (4) ataupun PP No. 55 pasal 14 ayat (1) berbentuk pendidikan diniyah, dan pesantren. Ayat (2) dan ayat (3) menjelaskan bahwa kedua model pendidikan tersebut dapat diselenggarakan pada jalur formal, nonformal dan informal.

Lantas pertanyaannya adalah bagaimana posisi MI, MTs, MA/MAK dan PT Islam penyelenggara pendidikan keagamaan Islam? Apakah juga berposisi sama dengan diniyah dan pesantren? Sebab pada akhirnya pada pasal 16 UU Sisdiknas disebutkan bentuk kelembagaan dari proses pendidikan diniyah juga menggunakan nama MI, MTs dan MA/ MAK untuk menyebut pendidikan diniyah dasar, dan pendidikan diniyah menengah.

Tema menarik lain dalam PP 55 tahun 2007 ini adalah kemandirian dan kekhasan pendidikan keagamaan sebagaimana tercantum dalam pasal 12 ayat (2) yaitu: "Pemerintah melindungi kemandirian dan kekhasan pendidikan keagamaan selama tidak bertentangan dengan tujuan pendidikan nasional". Sejak dahulu kekhasan pendidikan 
diniyah dan pesantren adalah hanya mengajarkan materi agama Islam saja, dan tidak materi lain.

Namun dalam pasal 18 PP No. 55 tahun 2007 disebutkan untuk pendidikan diniyah formal pada ayat (1), kurikulum pendidikan diniyah dasar formal wajib memasukkan muatan pendidikan kewarganegaraan, bahasa Indonesia, matematika, dan ilmu pengetahuan alam dalam rangka pelaksanaan program wajib belajar. Begitu juga untuk pendidikan diniyah menengah formal. Kurikulum pendidikan diniyah menengah formal wajib memasukkan muatan pendidikan kewarganegaraan, bahasa Indonesia, matematika, ilmu pengetahuan alam, serta seni dan budaya.

Jika memang ada keinginan pemerintah untuk memberi pilihan kemandirian dan kekhasan pada "sekolah" di lingkup pendidikan Islam, tentunya tidak akan ada lagi narasi sebagaimana pada pasal 18 ayat (1). Di sinilah terjadi benturan yang perlu disikapi secara lebih bijak. Sebab, sejak awal hadirnya pendidikan Islam tampaknya lebih kuat ke arah pendidikan non-formal, dan bukan formal sebagaimana pada pasal-pasal di atas. Selain itu, materi yang banyak diajarkan adalah berkisar tema-tema agama, dan tidak membicarakan mata pelajaran sebagaimana yang dimaksud.

Jika yang dimaksud adalah MI, MTs, dan MA/MAK sebagai wujud dari sekolah formal pendidikan Islam, maka sejarah telah mencatat saat ini proporsi kurikulum bidang agama dengan kurikulum bidang kajian umum di madrasah dapat dinyatakan telah meninggalkan ciri madrasah sebagai pendidikan keagamaan Islam. Proporsi 70\% bidang umum dan $30 \%$ bidang agama, lebih dimaksudkan untuk penyetaraan pendidikan di madrasah dengan sekolah pada jenjang yang sama.
Lantas apakah dengan penambahan proporsi kurikulum bidang umum lebih tinggi dibanding kurikulum bidang agama dapat serta merta meningkatkan mutu pendidikan di madrasah? Pada kenyataannya malah terjadi dampak yang tidak selamanya positif. Sebut saja masalah jati diri madrasah.

Sejak mula hadir sebenarnya madrasah lebih berfokus pada pendidikan keagamaan dan keislaman. Dengan perubahan orientasi tersebut justru madrasah saat ini kehilangan jati dirinya, dan lebih parah lagi kesulitan pula untuk merebut peran dalam konteks pendidikan nasional, jika dibandingkan dengan sekolah-sekolah umum di bawah pembinaan Kementerian Pendidikan Nasional.

Pada masa-masa yang akan datang, dalam hal pengembangan kurikulum, tampaknya madrasah masih akan terus dihadapkan pada dilema dikotomi keilmuan. Setia dengan tujuan awal hadirnya sebagai pengembang ilmu-ilmu keislaman, atau sesuai dengan tuntutan kebutuhan pasar untuk melakukan perubahan kurikulum yang ukurannya adalah pragmatism sebagai upaya pemenuhan kebutuhan hidup peserta didik. Tentu saja, pilihan atas itu semua akan memiliki resiko yang tidak sama dalam pengembangan materi pembelajaran, orientasi serta proses pembelajarannya.

Sementara itu untuk pendidikan diniyah non-formal disebutkan dalam pasal 21 ayat (1) yaitu pendidikan diniyah nonformal diselenggarakan dalam bentuk pengajian kitab, Majelis Taklim, Pendidikan al-Qur'an, Diniyah Takmiliyah, atau bentuk lain yang sejenis. Adapun untuk proses penyelenggaraannya tertuang dalam pasal yang sama ayat (5) yaitu, penyelenggaraan diniyah takmiliyah dapat dilaksanakan secara terpadu dengan SD/MI, SMP/MTs, SMA/MA, SMK/MAK atau pendidikan tinggi. 
Jika untuk lembaga pendidikan keagamaan Islam yang diformalkan saja memiliki banyak hambatan, maka persoalan yang senada juga pasti dialami oleh pendidikan diniyah nonformal. Tentunya bentuk-bentuk pendidikan diniyah non-formal di atas lebih dimaksudkan sebagai upaya menyiasati ketidakmungkinan peserta didik mengikuti proses pendidikan secara formal. Hanya saja jika itu terjadi, maka persoalannya adalah bagaimana upaya kesetaraannya? Lembaga mana yang akan dijadikan sebagai model ideal bagi penyetaraan pendidikan diniyah non-formal ini?

Sementara persoalan pendidikan kesetaraan di lingkup Kementerian Pendidikan Nasional sendiri belum seluruhnya tuntas, setidaknya untuk masalah home schooling yang hingga hari ini masih tarik ulur tentang penyelenggaraannya. Tentunya Kemenag juga harus mulai mengantisipasi untuk membuat desain model penyetaraan bagi pendidikan diniyah non-formal ini. Sebab rasanya tidak adil, tidak menghargai mereka yang telah menempuh pendidikan selama kurun waktu tertentu, namun tidak memberi atribut kelulusannya.

\section{Kesimpulan}

Paparan di atas tidak bermaksud untuk memposisikan Kemenag sebagai penentu kebijakan pendidikan Islam untuk serta merta menyerahkan tanggungjawab pendidikan lembaga Islam pada Kementerian Pendidikan Nasional, walau hal ini sebagai sebuah solusi terbaik. Namun, setidaknya untuk masa datang kebijakan yang muncul dari Kemenag terkait dengan pendidikan Islam, bukanlah kebijakan yang kemudian sama dengan kebijakan di Kementerian Pendidikan Nasional. Setidaknya, jika ada kebijakan yang sama, maka kebijakan itu lahir dalam kurun waktu yang sama, dengan formulasi dan aturan main yang juga sama, meski dikeluarkan oleh dua instansi yang berbeda.

Pada sisi tersebut, tampak perlunya dilakukan kerjasama sinergis antara Kemenag dan Kementerian Pendidikan Nasional untuk secara serius mengembangkan pendidikan Islam. Sebab, apapun adanya pendidikan Islam merupakan bagian integral dari sistem pendidikan nasional. Artinya jika saat ini masih dipahami posisi pendidikan Islam sebagai subsistem dalam konteks pendidikan nasional sebagai sekadar berfungsi sebagai pelengkap (suplemen), maka hendaklah terjadi pergeseran "peran" dari sekadar suplemen menjadi bagian yang juga turut berperan dan menentukan (substansial).

Namun, jika masih tetap dalam posisi yang sama, maka sudah selayaknya Kemenag memberikan hak pengaturan pendidikan kepada Kementerian Pendidikan Nasional, sehingga untuk masa datang pengaturan masalah-masalah pendidikan berada pada satu unit Departemen saja, dan tidak seperti sekarang ini banyak departemen mengelola pendidikan kedinasan dan non-kedinasan.

\section{Daftar Pustaka}

Idrus, Muhammad. 1997. Karakteristik dan Dimensi Moral Anak Didik dalam Pendidikan, dalam Pendidikan Islam dalam Peradaban Industrial, Muslih Usa dan Aden Wijdan SZ (Edit). Yogyakarta: Aditya Media.

Mulyana, Rohmat. 2008. Quo Vadis Madrasah? http:// pendis.Kemenag.go.id/ madrasah/Insidex.php?i_367= at02100032. Diakses pada 9 September 2008. 
Peraturan Pemerintah (PP) Nomor 55 tahun 2007 Tentang Pendidikan Agama Dan Pendidikan Keagamaan.

Rozihan. 2008. Merombak Pendidikan Agama Islam. From http://www.suaramerdeka. com/harian/0501/07/opi3.htm. Download 9 September 2008.
UUSPN No. 20 Tahun 2003.

Zamroni. 1995. Pendidikan Tinggi Islam di Indonesia. dalam Al-Islamiyah. Nomor 1 Tahun V 1995. Media LPPAI UII Yogyakarta. 